\title{
Complex zoning of olivine in archetypal kimberlites provides new insights into the evolution of kimberlite magmas
}

\author{
Emilie Lim ${ }^{1}$, Andrea Giuliani ${ }^{1,2}$ and David Phillips ${ }^{1}$ \\ ${ }^{1}$ KiDs (Kimberlites and Diamonds), School of Earth Sciences, The University of Melbourne, Parkville, VIC, \\ Australia,emilielc@student.unimelb.edu.au \\ ${ }^{2}$ ARC Centre of Excellence for Core to Crust Fluid Systems (CCFS) and GEMOC, Department of Earth and \\ Planetary Sciences, Macquarie University, North Ryde, NSW, Australia
}

\section{Introduction}

Kimberlites are rare, hybrid igneous rocks consisting of primary magmatic components, and mantle and crustal-derived xenoliths. During ascent, kimberlite magmas transport, assimilate and metasomatise material along the magma conduit. The combination of these processes contributes to generate the peculiar hybrid character of kimberlites (e.g., Giuliani et al. 2016). The degree to which assimilation influences kimberlite melts has been difficult to constrain from the composition of magmatic minerals alone. Olivine is the most abundant phase in kimberlites and, therefore, its composition can provide valuable information about the evolution of kimberlite magmas. In kimberlites, olivine is typically zoned with a mantle-derived, xenocrystic core, and an overgrowth (rim) that crystallises from the kimberlite melt (e.g., Brett et al. 2009; Pilbeam et al. 2013).

In this study, fresh olivine grains from five kimberlites, from different localities in Brazil (Limpeza18), Canada (Grizzly and Koala from the Ekati property) and South Africa (Samada and New Robinson from the Kaalvallei cluster), were selected for major and trace element analysis. The olivine grains include macrocrysts $(0.5-10 \mathrm{~mm})$, phenocrysts $(>0.5 \mathrm{~mm})$ and microphenocrysts $(0.1-0.5 \mathrm{~mm})$.

\section{Results}

BSE-SEM images (Figure 1) and EMP analyses (Figure 2 and 3) show that olivine includes a core, rim and internal layer between the core and rim.
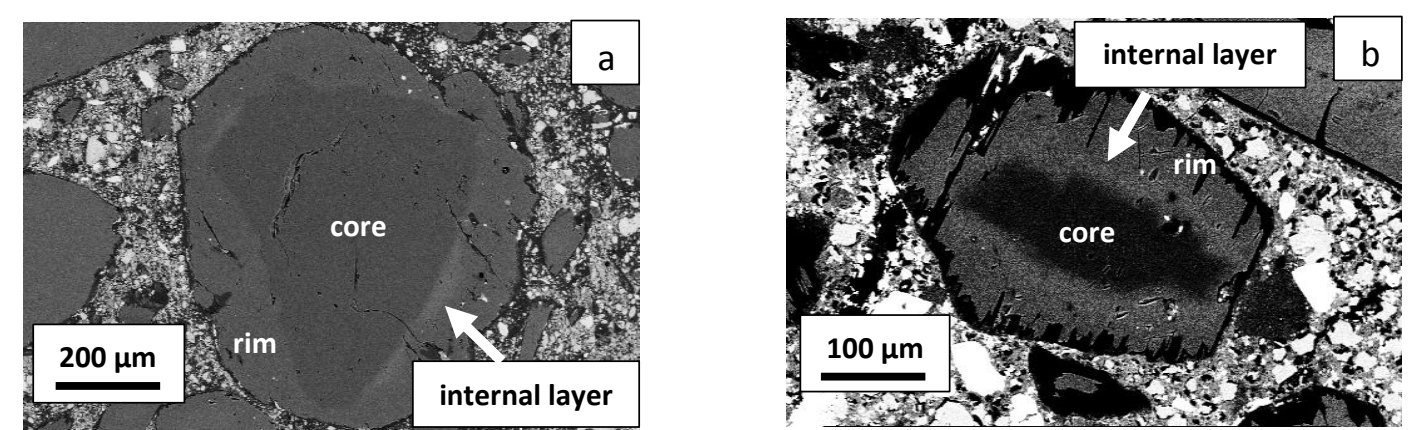

Figure 1. BSE-SEM images of a) a zoned olivine macrocryst from the Grizzly kimberlite; and b) a zoned olivine microphenocrysts from the Limpeza-18 kimberlite.

Olivine grains have cores with varying proportions of Mg-rich ('mantle') and Fe-rich ('megacrystic') components (Figure 2). 'Mantle' cores are characterised by Mg\# of 89-95, high $\mathrm{NiO}(>0.20 \mathrm{wt} . \%$ ) and low $\mathrm{CaO}$ (typically < 0.11 wt.\%) contents. 'Megacrystic' cores comprise compositions with Mg\# of 7888 , decreasing $\mathrm{NiO}$ contents from 0.36 to $0.03 \mathrm{wt} . \%$ and higher $\mathrm{CaO}$ concentrations $(<0.19 \mathrm{wt} . \%)$ than the 'mantle' cores. 


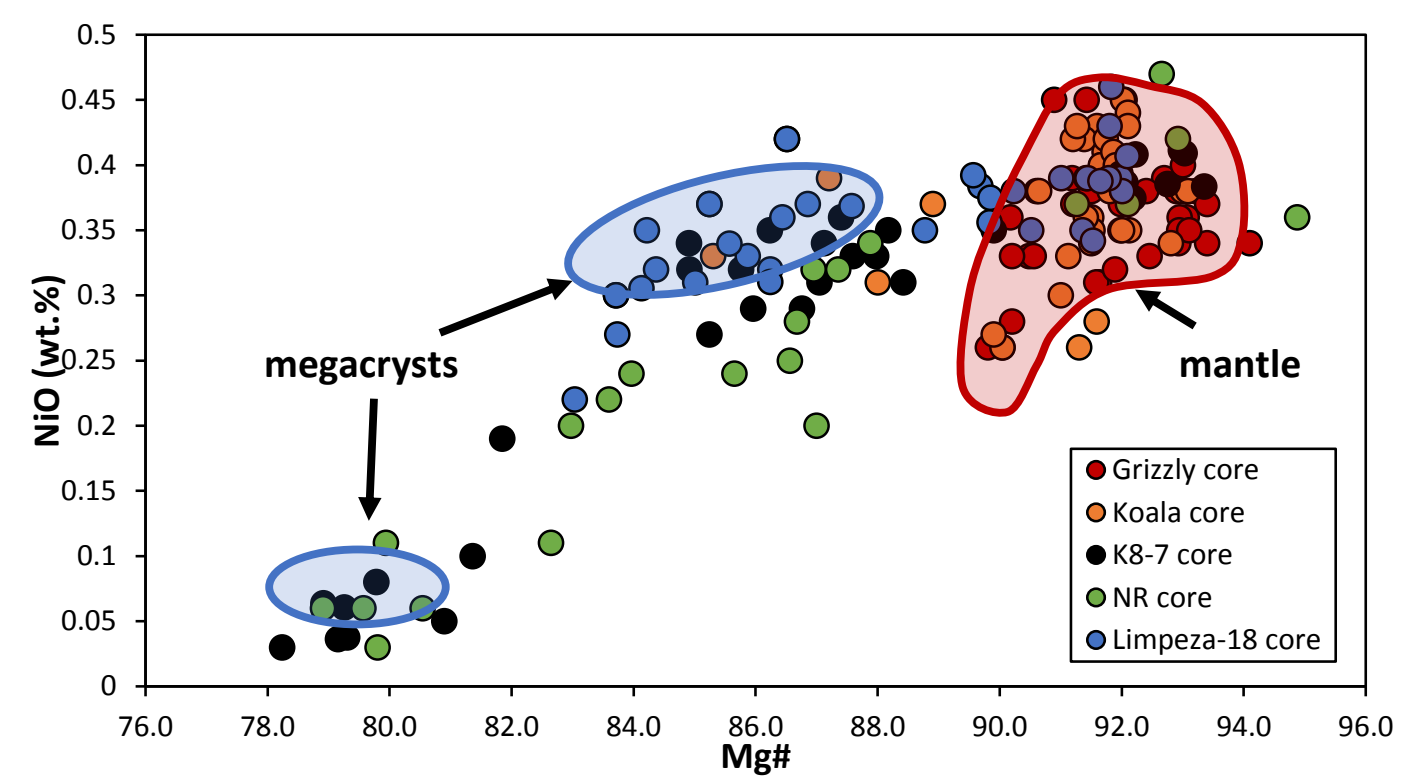

Figure 2. $\mathrm{NiO}$ (wt.\%) vs. Mg\# plot of olivine cores from Grizzly, Koala, Samada (K8-7), New Robinson (NR), and Limpeza-18 kimberlites, with representative compositional fields of olivine from mantle-derived rocks, i.e., 'mantle' peridotites (red field; Bussweiler et al. 2015) and 'megacrysts' (blue fields; Gurney et al. 1979) which may be genetically related to the olivine cores.

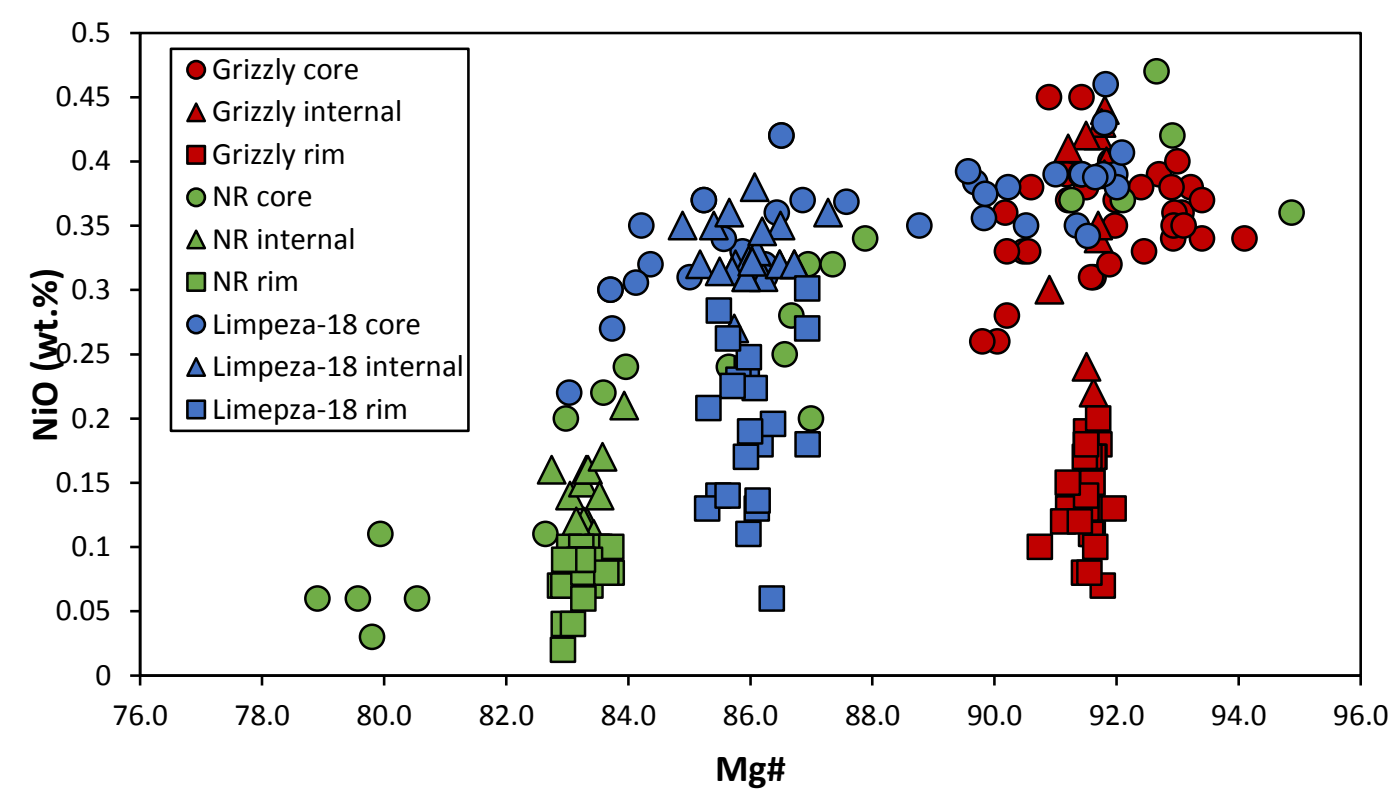

Figure 3. $\mathrm{NiO}$ (wt.\%) vs. Mg\# plot showing the compositions of cores, internal layers and rims of olivine in three studied kimberlites. NR = New Robinson; internal = internal layer.

The internal layers of olivine exhibit higher concentrations of $\mathrm{NiO}$ (e.g., 0.11-0.21 wt.\% for New Robinson and 0.27-0.38 wt.\% for Limpeza-18) than their respective rims. They also have low $\mathrm{CaO}(<$ 0.13 wt.\%) contents, with restricted Mg\# ranges (e.g., 91-92 for Grizzly and 85-87 for Limpeza-18). Olivine rims in all studied kimberlites show decreasing $\mathrm{NiO}$ concentrations typically from $0.30 \mathrm{wt} . \%$ to values as low as $0.02 \mathrm{wt} . \%$, increasing $\mathrm{CaO}$ contents (0.07- 0.30 wt.\%) and constant $\mathrm{Mg \#} \mathrm{(e.g.,} \mathrm{91-}$ 92 for Grizzly and 85-87 for Limpeza-18). It is noteworthy that in each kimberlite, olivine rims and internal layers show overlapping $\mathrm{Mg \#}$ values. 
In kimberlites containing higher proportions of olivine with 'megacrystic' (i.e., Fe-rich) core compositions, the olivine internal layers and rims are richer in $\mathrm{Fe}(\mathrm{Mg \#} \mathrm{<} \mathrm{85)} \mathrm{than} \mathrm{those} \mathrm{of} \mathrm{olivine}$ grains whose cores are dominated by 'mantle' (i.e., Mg-rich) core compositions (Figure 3).

\section{Discussion}

The overlapping compositions of 'mantle' cores and olivine in peridotites from the underlying lithospheric mantle suggest that these cores probably derive from disaggregated peridotites (e.g., Bussweiler et al. 2015; Dawson et al. 1980). 'Megacrystic' cores with Mg\# of 82-88, present in different abundances at Koala, Limpeza-18, Samada and New Robinson, significantly overlap with the high Ni (0.30-0.40 wt.\% NiO) and $\mathrm{Mg}(\mathrm{Mg} \#$ 84-88) group of olivine megacrysts from the Monastery kimberlite (Gurney et al. 1979). 'Megacrystic' cores with Mg\# of 78-81, present in the Samada and New Robinson kimberlites, overlap with the second group of Monastery megacrysts (i.e., $\mathrm{Mg} \# 78-81 ; \mathrm{NiO}=<0.11$ wt.\%). Therefore, it can be inferred that olivine 'megacrystic' cores may be genetically linked to the megacryst suite of xenoliths found in kimberlites worldwide (see also Moore and Costin 2016). The two distinct types of olivine cores were entrained by the ascending kimberlite magma, which then overgrew new olivine around these cores. Similar Mg\# compositions of internal layers and rims suggest that the internal layers were produced by the same kimberlite melt(s) that crystallised the rim. We speculate that the internal layer represents the point at which olivine first starts to crystallise in kimberlites, due to the high $\mathrm{NiO}$ and low $\mathrm{CaO}$ contents. Subsequent crystallisation then results in the formation of olivine rims with lower $\mathrm{NiO}$ and higher $\mathrm{CaO}$ concentrations.

Assimilation of mostly mantle peridotitic material (e.g., Grizzly and Koala where the cores are dominantly $\mathrm{Mg}$-rich) drives the kimberlite melt towards a Mg-rich composition with formation of high$\mathrm{Mg \#}$ internal layers and rims. Conversely, assimilation of more megacrystic component (e.g., Samada and New Robinson where the cores are dominantly Fe-rich), enriches the kimberlite melt in Fe with crystallisation of low-Mg\# internal layers and rims. The Limpeza-18 kimberlite provides an intermediate case between the Ekati and Kaalvallei kimberlites. This study therefore provides strong evidence that assimilation of different types of mantle-derived material can generate kimberlites with highly variable compositions, and underlines the extent to which assimilation contributes in making each kimberlite unique.

\section{References}

Brett RC, Russell JK, Moss S (2009) Origin of olivine in kimberlite: Phenocryst or impostor? Lithos 112:201-212

Bussweiler Y, Foley SF, Prelević D, Jacob DE (2015) The olivine macrocryst problem: New insights from minor and trace element compositions of olivine from Lac de Gras kimberlites, Canada. Lithos 220-223:238-252

Dawson JB, Smith JV, Hervig RL (1980) Heterogeneity in Upper-mantle Lherzolites and Harzburgites. Philosophical Transactions of the Royal Society of London Series A, Mathematical and Physical Sciences 297(1431):323-332

Giuliani A, Phillips D, Kamenetsky VS, Goemann K (2016) Constraints on kimberlite ascent mechanisms revealed by phlogopite compositions in kimberlites and mantle xenoliths. Lithos 240243:189-201

Gurney JJ, Jakob WRO, Dawson JB (1979) Megacrysts from the Monastery kimberlite pipe. In: Boyd FR, Meyer HOA (eds) The mantle sample 2nd International Kimberlite Conference, vol. American Geophysical Union, Washington, DC, pp 227-243

Moore A, Costin G (2016) Kimberlitic olivines derived from the Cr-poor and Cr-rich megacryst suites. Lithos 258:215-227

Pilbeam LH, Nielsen TFD, Waight TE (2013) Digestion Fractional Crystallization (DFC): an Important Process in the Genesis of Kimberlites. Evidence from Olivine in the Majuagaa Kimberlite, Southern West Greenland. Journal of Petrology 54(7):1399-1425 